Рекомендована д. фрармац. наук, проф. В. С. Кисличенко

УДК $58.083+582.689$

DOI 10.11603/2312-0967.2016.3.6831

\title{
ДОСЛІДЖЕННЯ АНАТОМІЧНОЇ БУДОВИ НАДЗЕМНИХ ОРГАНІВ PRIMULA JULIAE KUSN
}

\author{
() С. М. Марчишин, А. В. Сініченко, Л. М. Сіра
}

\author{
ДВНЗ «Тернопільський державний медичний університет імені І. Я. Горбачевського \\ МОЗ України» \\ Національний фрармацевтичний університет, Харків
}

\begin{abstract}
Резюме: вперше здійснено дослідження особливостей анатомічної будови надземних органів первоцвіту (примули) Юлії родини первоцвіті, в результаті якого виявлено їх характерні мікроскопічні діагностичні ознаки. Встановлені мікродіагностичні ознаки дають можливість ідентифікувати лікарську рослинну сировину і можуть бути використані для розробки проекту АНД.

Ключові слова: примула Юлія, листя, квітки, анатомічна будова.
\end{abstract}

Вступ. Ще з прадавніх часів у багатьох країнах представники родини первоцвіті знайшли широке застосування як цілющі рослини. Як сировину 3 лікувальною метою застосовують листя, квітки та кореневища $з$ коренями. Примула проявляє потогінну, сечогінну, відхаркувальну і загальнозміцнювальну дію. Це вітамінна рослина, вона сприяє поліпшенню фуннцій надниркових залоз, а також нормалізує процес виділення шлункового соку. Поряд з цим, висушену сировину рослини призначають при грипі, ГРЗ, ангінах, бронхітах і риносинуситах. Трава первоцвіту має слабку снодійну і заспокійливу дію, а також ефрективна при неврозах і мігрені. Популярним також $€$ олія примули, що сприяє відновленню імунітету, ефективна в клімактеричному періоді і при болісних менструаціях. Олію примули часто використовують для реабілітації людини після перенесених інтоксикацій та важких інфекційних захворювань, ефективна при високому артеріальному тиску та стенокардії $[1,2,6,7,10]$.

Первоцвіт Юлії (примула Юлії) - Primula juliae Kusn., родина первоцвіті (Primulaceae), секція Юлії (Julia) - багаторічна трав'яниста тіньовитривала, довго вегетуюча і рясно квітуча дернинна рослина-гігрофріт. Кореневище коротке, косе, з пучком бурих коренів. Листки черешкові, без прилистків, завдовжки близько 10 см, утворюють подушку. Листкова пластинка близько 3 см, зморшкувата, яйцеподібна або округла з серцеподібною основою і великогородчастим краєм. Генеративних пагонів 3-14. Квітки розташовані найчастіше поодинці на тонких квітконіжках заввишки до 10-15 см. Чашечка 35 зрослих до середини загострених чашолистків, що мають виступаючі над поверхнею темні жилки. Віночок до 3 см в діаметрі, пурпуровий, карміново-червоний, фріоле- тово-бузковий, $з$ жовтуватим глазком, інколи білий. Квіткова трубка завдовжки до 2 см, верхівка пелюсток відгину 3 глибокою виїмкою. Фертильні тичинки супротивні пелюсткам, прирослі до трубки віночка. Приймочка маточки головчаста $[2-5,8]$.

Аналіз даних спеціалізованої літератури свідчить про відсутність систематизованих відомостей про морфолого-анатомічну будову різних, зокрема надземних, органів цієї рослини.

Мета роботи - вивчення анатомічної будови надземних органів Primula juliae Kusn. та встановлення мікроскопічних діагностичних ознак, необхідних для ідентиорікації рослинної сировини.

Методи дослідження. Для дослідження було використано листки і квітки примули Юлії, заготовлені під час цвітіння (травень 2015 р.) рослини на науково-дослідних ділянках Національного ботанічного саду імені М. М. Гришка НАН України. Мікроскопічний аналіз проводили, використовуючи висушену сировину, фріксовану в суміші спирт-гліцерин-вода (1:1:1), та включно рідини тимчасових мікропрепаратів - розчини гліцерину та хлоралгідрату. Дослідження поперечних і поздовжніх зрізів, відпрепарованої епідерми та препаратів 3 поверхні проводилися 3 використанням загальноприйнятих методик, мікроскопів МБС 9, МС 10 (окуляри X5, Х10, 15, об'єктиви Х10, Х40). Мікрофротограсрії зроблено фротокамерою Samsung PL50 [9].

Результати й обговорення. Листок. 3 поверхні клітини нижньої епідерми між жилками (рис. 1) паренхімні, бічні стінки звивисті, тонкі або з незначними дрібночоткоподібними потовщеннями, вкриті тонким шаром ніжно-складчастої кутикули. Серед безбарвних епідермальних клітин розміщені й секретуючі, 3 жовтуватим вмістом. Продихів багато,

ISSN 2312-0967. Pharmaceutical review. 2016. № 3 
Фітохімічні дослідження

Phytochemical researches
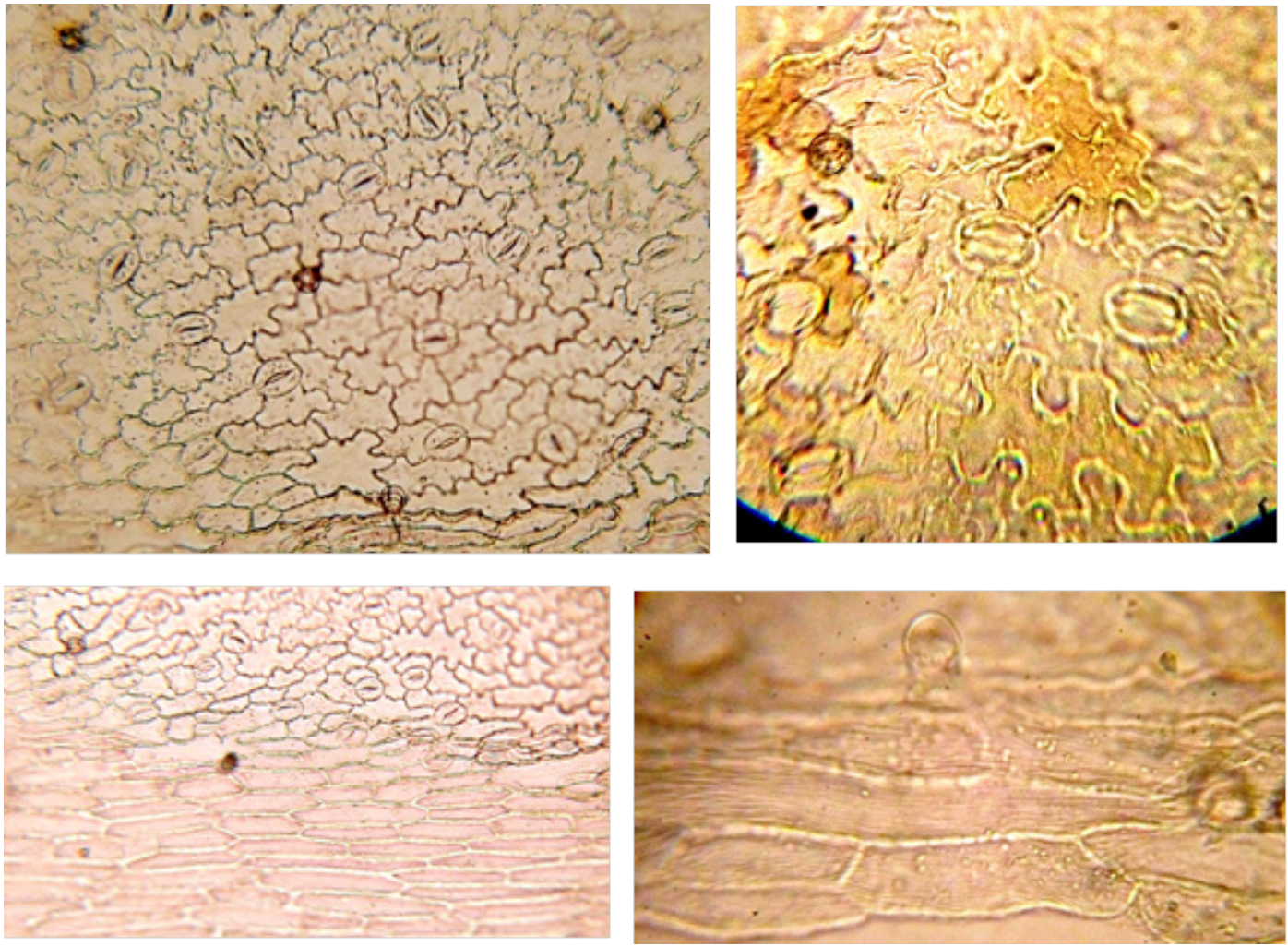

Рис. 1. Нижня епідерма листкової пластинки.

за типом аномоцитні, оточені 5-6 епідермальними клітинами. Серед основних клітин рівномірно розподілені залозисті волоски 3 округлою темною головкою, короткою ніжкою і 5-6-клітинною розеткою. Над жилками (рис. 1) епідермальні клітини видовжені, вузькі, прямостінні, зі скошеними або клиноподібними кінцями, виразними поздовжніми складками кутикули. Добре помітні нечасті залозисті волоски. Клітини верхньої епідерми (рис. 2) крупніші, їх бічні стінки менш звивисті, чисельність продихів значно менша, а залозистих волосків - більша. Епідерма по краю пластинки (рис. 3) вкрита товстим поздовжньоскладчастим кутикулярним шаром. Епідермальні й субепідермальні клітини з яскраво-оранжевим вмістом. Спеціалізовані клітини утворюють регулярні, розміщені на відстані 7-10 клітин, горбкуваті вирости, що несуть залозисті волоски косо спрямовані до верхівки пластинки. Їх головка одноклітинна, куляста, зморшкувата, з темним вмістом. Ніжка по ширині така ж, як діаметрі головки, складається 3 1-3 тонкостінних бочкоподібних клітин. Базальна клітина 3 товстостінним валиком, який залишається при обламуванні волоска. Верхівка листкової пластинки увінчана гідатодою.

Листкова пластинка за анатомічною будовою дорсовентральна, амфістоматична. Стовпчаста хло-
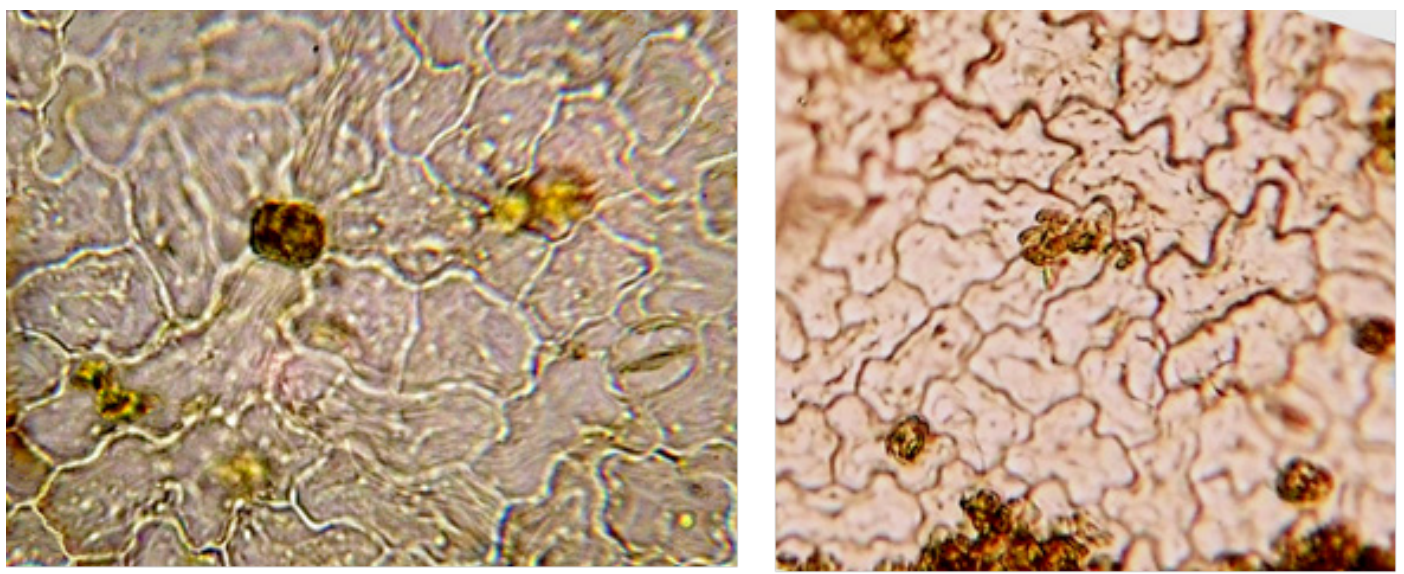

Рис. 2. Верхня епідерма листкової пластинки.

ISSN 2312-0967. Фармацевтичний часопис. 2016. № 3 

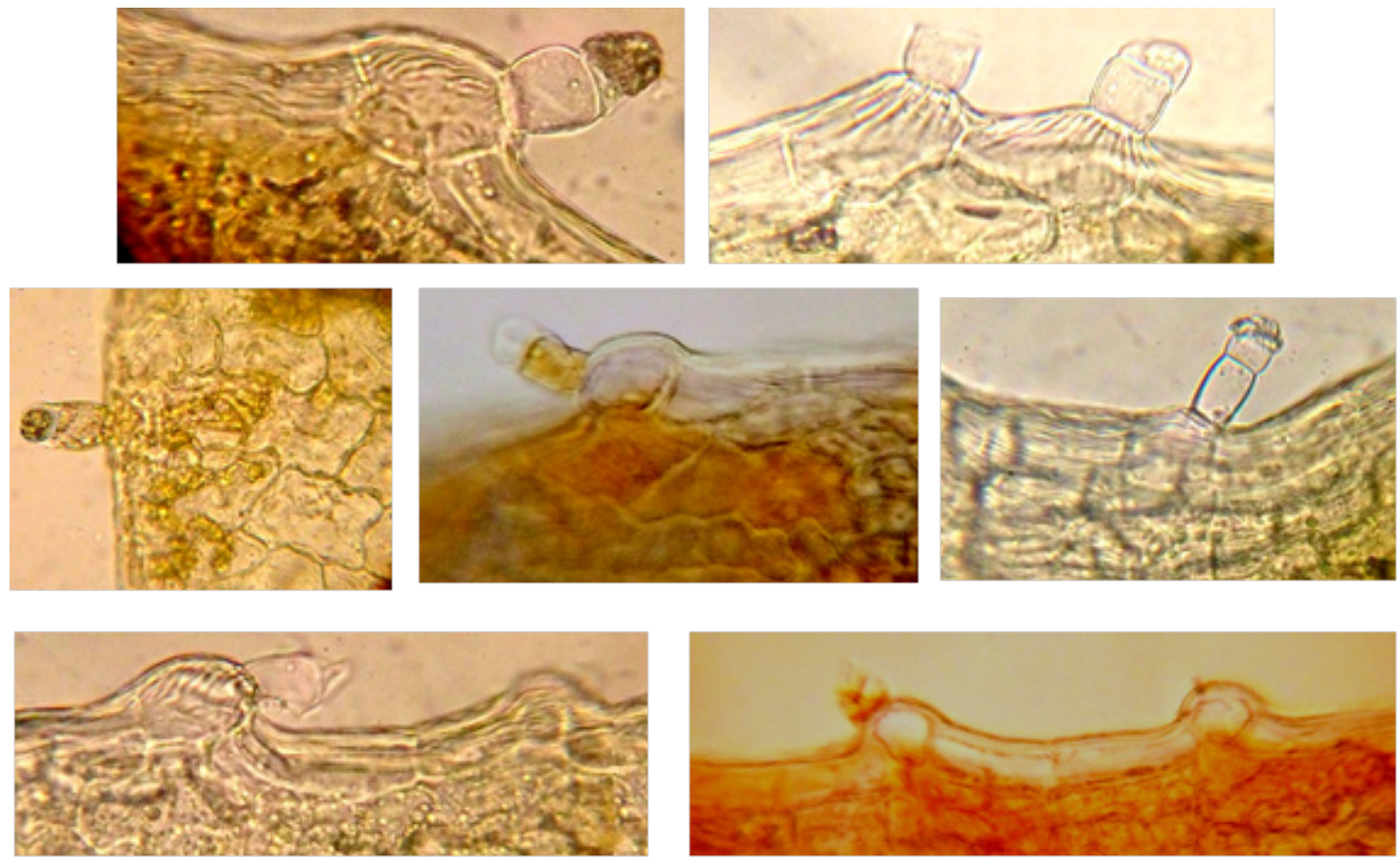

Рис. 3. Край листкової пластинки.

ренхіма 1-2-шарова, в губчастій паренхімі багато ідіобластів з оранжевим секретом.

Черешок (рис. 4) на поперечному зрізі овально-напівкулястий, з крильцями. Епідерма залозиста, деякі іiі клітини сосочкуваті, заповнені жовто-оранжевим секретом. Головчастих трихом менше, ніж на пластинці. Під епідермою - 1-2 шари коленхіматозної тканини.

Провідну систему складає центральний пучок і по одному дрібному пучечку ближче до крилець. Центральний пучок у верхній частині черешка округлий, замкнений концентрично. У подальшому він збільшується і стає напівкулястим. Добре розвинена секретуюча ендодерма, в паренхімі фолоеми, ксилеми і поза пучками багато округло-овальних або лопатевих ідіобластів і членистих молочників з оранжевим секретом. Основна паренхіма крупноклітинна, з невеликими міжклітинниками.

Квітконосне стебло. Стебло (рис. 5) на зрізах округло-лопатеве. Епідермальні клітини 3 поверхні продовгуваті, більш або менш вузькі, з тонкими або помірно стовщеними оболонками, вкриті шаром кутикули. Найчастіше усі або їх більшість містить оранжевий секрет. Волоски і продихи малочисельні. Первинна кора широка, без коленхіми, утворена пухкою паренхімою 3 секретуючими ідіобластами. Осьовий циліндр вузький, складається 3 5-7 маленьких колатеральних провідних пучків, зближених або об'єднаних між собою. Серед гістологічних елементів переважають секреторні клітини, орлоема пучків розвинена дуже слабко, судини ксилемі тонкі, їх кількість обмежена. Серцевина мізерна, чітко не виді- ляється, у центрі частково руйнується, паренхіма 3 оранжевим вмістом.

Частини квітки. Зовнішню епідерму чашечки (рис. 6) складають трохи видовжені базальні клітини із хвилясто-звивистими бічними і потовщеними зовнішніми оболонками, вкритими поздовжньо-складчастою кутикулою. Продихи зустрічаються рідко. Клітини внутрішньої епідерми видовжені, майже прямостінні. Епідерма відгину пелюсток (рис. 6) сосочкоподібна, клітини епідерми трубки продовгуваті, тонкі. Жилки супроводжують членисті молочники 3 жовтооранжевим вмістом.

Висновки. Вперше здійснено дослідження особливостей анатомічної будови надземних органів примули Юлії, в результаті якого виявлено їх характерні мікроскопічні діагностичні ознаки:

- Сегменти листкової пластинки: клітини нижньої епідерми між жилками паренхімні, бічні стінки звивисті, серед безбарвних епідермальних клітин розміщені секретуючі, 3 жовтуватим вмістом, продихів багато, серед основних клітин рівномірно розподілені залозисті волоски; клітини верхньої епідерми більші, їх бічні стінки менш звивисті, продихів небагато, залозистих волосків багато. Епідермальні й субепідермальні клітини з яскраво-оранжевим вмістом.

- Листкова пластинка дорсовентральна, амфрістоматична. Стовпчаста хлоренхіма 1-2-шарова, в губчастій паренхімі багато ідіобластів 3 оранжевим секретом.

- Черешок на поперечному зрізі овально-напівкулястий, з крильцями. Епідерма залозиста, деякі ії

ISSN 2312-0967. Pharmaceutical review. 2016. № 3 
Фітохімічні дослідження

Phytochemical researches
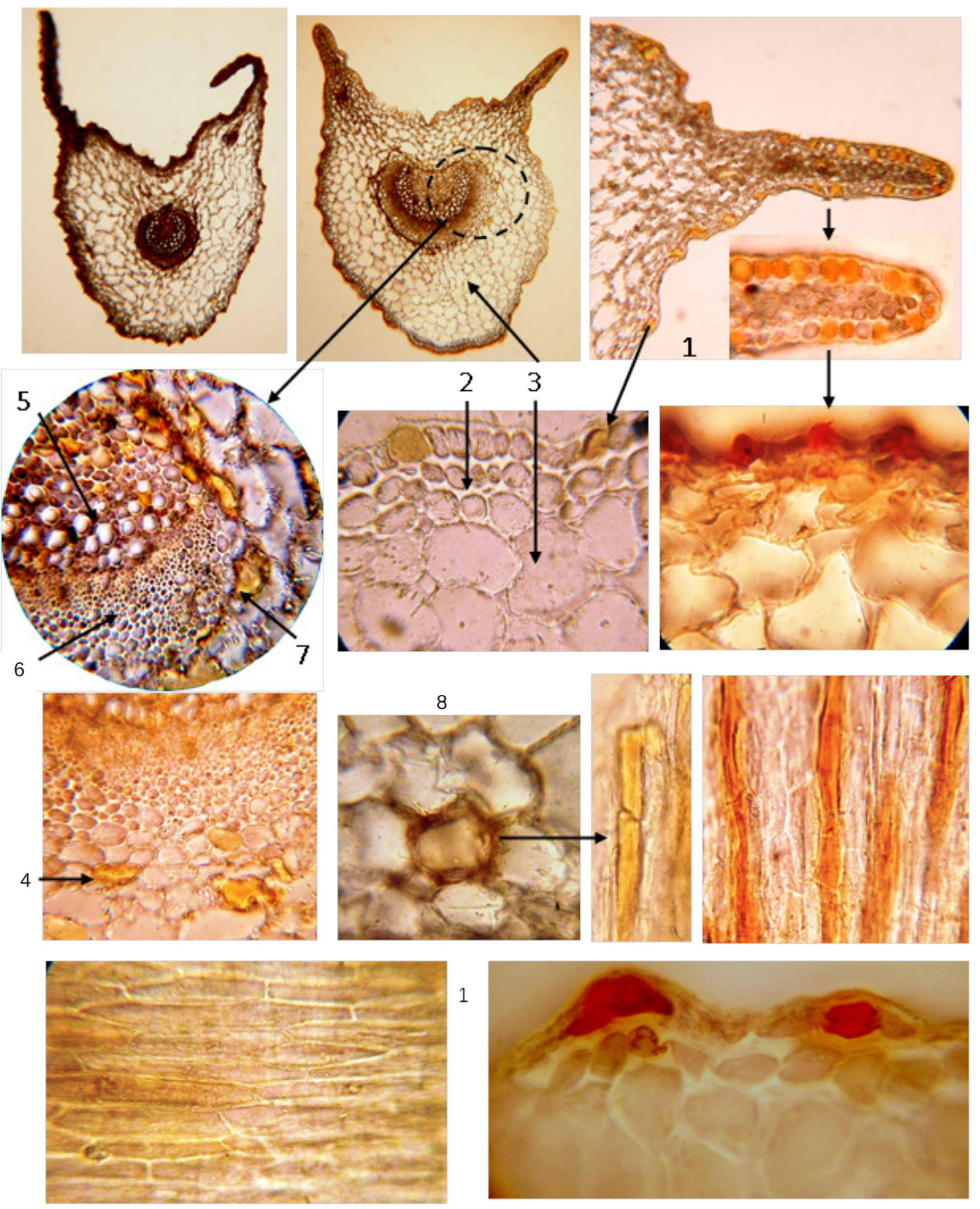

1

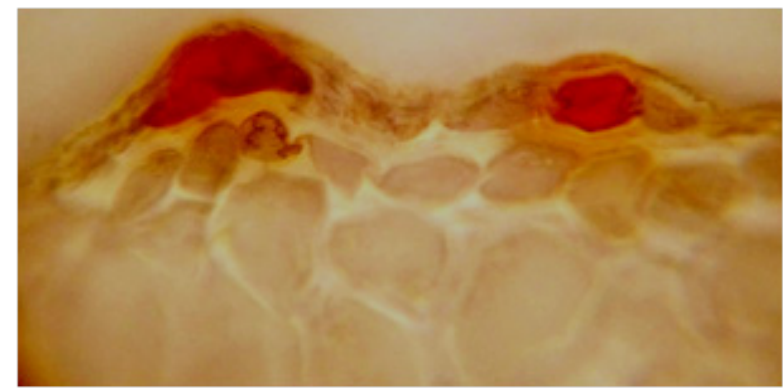

Рис. 4. Поперечні і поздовжні зрізи черешка:

1 - секретуюча епідерма, 2 - коленхіматозна паренхіма, 3 - основна паренхіма, 4 - ідіобласти 3 секретом, 5 - ксилема, 6 - фрлоема, 7 - ендодерма, 8 - членисті молочники (на поперечному і поздовжньому зрізах). 
Фітохімічні дослідження

Phytochemical researches

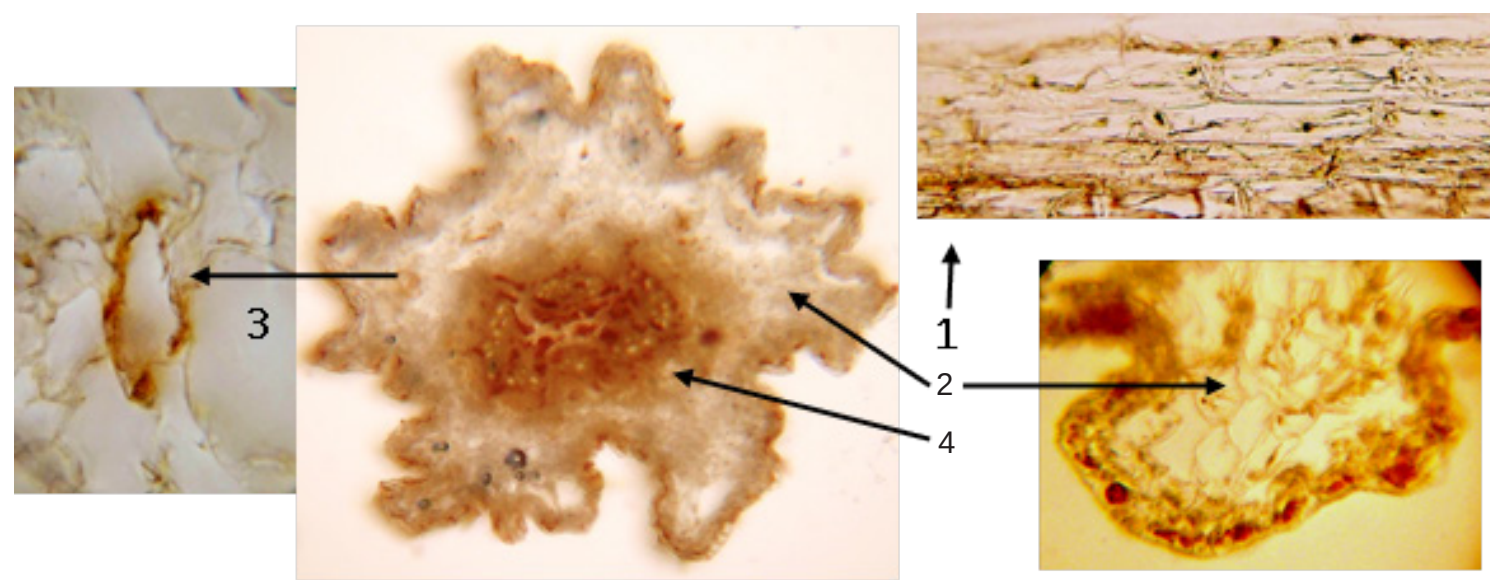

Рис. 5. Квітконос:

1 - епідерма з поверхні і на поперечних зрізах, 2 - корова паренхіма, 3 - секретуючі клітини, 4 - центральний циліндр.

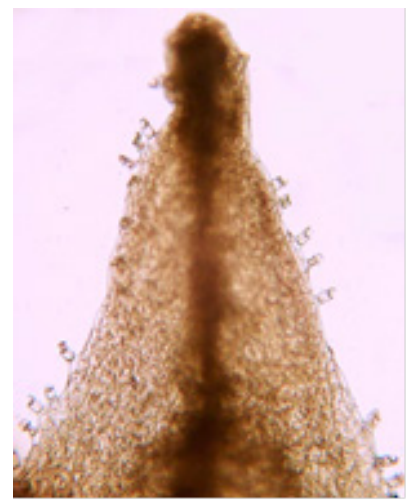

1

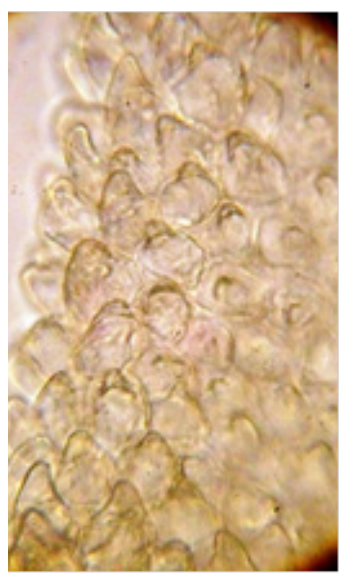

3

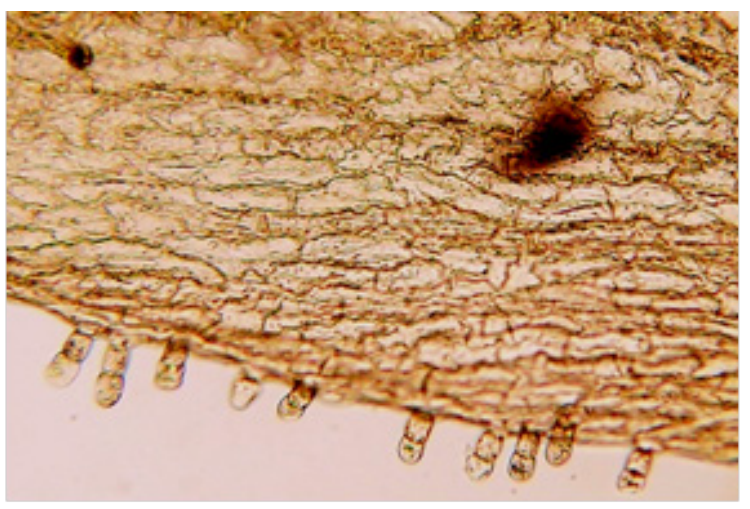

2

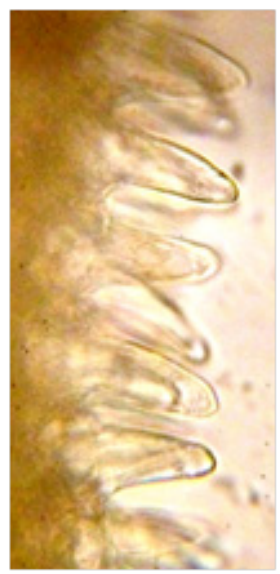

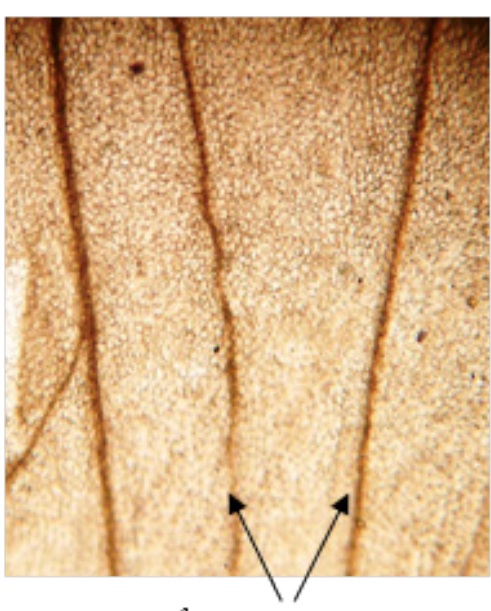

4
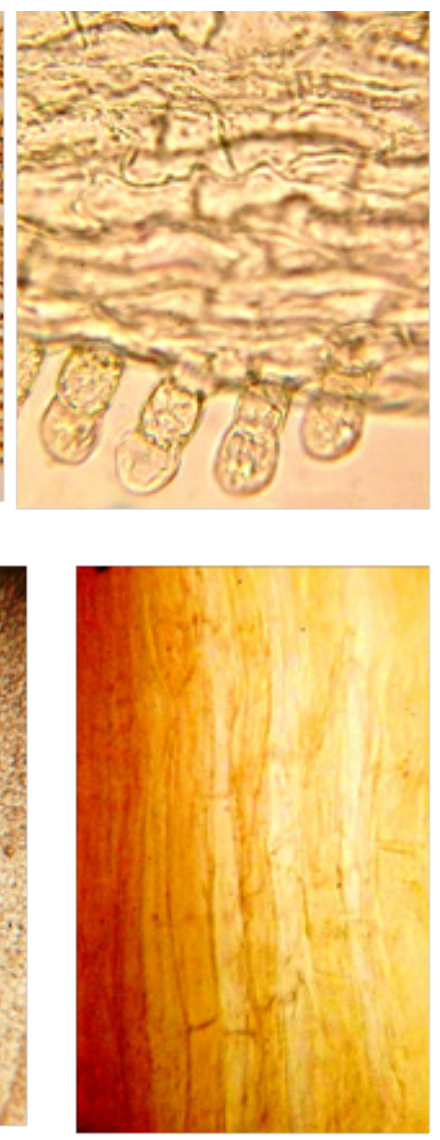

5

Рис. 6. Фрагменти частин квітки:

1 - зубець чашечки, 2 - зовнішня епідерма і край чашолистка, 3 - епідерма відгину віночка, 4 - жилки пелюстки, 5 - членисті трубки з секретом. 
клітини сосочкуваті, заповнені жовто-оранжевим секретом.

- Квітконосне стебло округло-лопатеве. Епідермальні клітини з поверхні продовгуваті, більш або менш вузькі, 3 тонкими або помірно потовщеними оболонками, вкриті шаром кутикули, більшість містить оранжевий секрет. Волосків і продихів небагаTO.

\section{Список літератури}

1. Вавилова Л. П. Примула: Научно-популярное издание

/ Л. П. Вавилова. - М. : Армада-пресс, 2001. - 32 с.

2. Грицак Л. Р. Рід Primula L. (Primulaceae) у фрлорі України (систематика, фрітохорологія, еволюція) : автореср. дис. на здобуття наук. ступеня канд. біол. наук: спец. 03.00.05 / Грицак Людмила Русланівна. - К., 2000. -20 c.

3. Довідник лікарських рослин. Первоцвіт весняний [Електронний ресурс]. - Режим доступу: http://proherbs. org.ua/view/325/

4. Жигунов О. Ю. К биологии редкого вида России Primula juliae Kusn. в условиях культуры / О. Ю. Жигунов, О. А. Каримова // ВЕСТНИК ВГУ, СЕРИЯ: ХИМИЯ БИОЛОГИЯ. ФАРМАЦИЯ. - 2014. - № 3. - С. 63-67.

5. Лікарські рослини: Енциклоп. довідник / Під ред.

А. М. Гродзінського. - К. : Голов. ред. УРЕ, 1989. -

C. 326-328.

6. Марчишин С. М. Анатомічна будова листя і квіток
- Частини квітки: епідерма відгину пелюсток сосочкоподібна, клітини епідерми трубки продовгуваті, тонкі. Жилки супроводжують членисті молочники 3 жовто-оранжевим вмістом.

Отримані дані будуть використані при складанні проектів методик контролю якості (МКЯ) на нову лікарську сировину «Примули Юлії листя» та «Примули Юлії квітки».

первоцвіту весняного (Primula Veris L.) / C. М. Марчишин, Л. Г. Шостак // Фармацевтичний журнал. - 2014. - № 6. - С. 69-76.

7. Перебойчук О. П. Перспективи використання представників роду Primula L. у квітникарстві лісостепу україни / О. П. Перебойчук // Науковий вісник НЛТУ України. - 2014. - Вип. 24.4. - С. 112-119.

8. Примула Юлии - Primula juliae Kusn. Энциклопедия декоративных садовых растений [Электронный ресурс]. - Режим доступа: http://flower.onego.ru/other/primul_p.html 9. Hajibagheri N. Electron Microscopy (Methods and Protocols) / Ed. by Nasser Hajibagheri // in Methods In Molecular Biology. - Vol. 117. - Humana Press, Totowa NJ., 2003. - 276 p.

10. Investigation of phenolic compounds of Primula veris L. / L. G. Shostak, S. M. Marchyshyn, S. S. Kozachok, R. V. Karbovska // Journal of Education, Health and Sport. - 2016. - Vol. 6, № 5. - P. 424-432.

\section{ИССЛЕДОВАНИЕ АНАТОМИЧЕСКОГО СТРОЕНИЯ НАДЗЕМНЫХ ОРГАНОВ РRIMULA JULIAE KUSN}

\section{С. М. Марчишин, А. В. Синиченко, Л. М. Серая}

гвУз «Тернопольский государственный медицинский университет имени И. Я. Горбачевского Мз Украины» Национальный фрармацевтический университет, Харьков

Резюме: впервые проведено исследование особенностей анатомического строения надземных органов первоцвета (примулы) Юлии семейства первоцветные, в результате которого определены их характерные микроскопические диагностические признаки. Установлены микродиагностические признаки дают возможность идентифрицировать лекарственное растительное сырье.

Ключевые слова: примула Юлия, листья, цветки, анатомическое строение.

\section{INVESTIGATION OF ANATOMICAL STRUCTURE OF OVERGROUND ORGANS PRIMULA JULIAE KUSN}

\section{S. M. Marchyshyn, A. V. Sinichenko, L. M. Sira}

\section{Horbachevsky Ternopil State Medical University} National University of Pharmacy, Kharkiv

Summary: for the first time there have been investigated features of anatomical structure of overground organs of primrose Julia from primrose family. As a result there have been identified individual microscopic diagnostic features. Established micro-diagnostic features make it possible to identify medicinal plants.

Key words: primrose Julia, leaves, flowers, anatomical structure. 